\title{
Long-term trends of air pollutant concentrations in Poland
}

\author{
Szymon Hoffman ${ }^{1, *}$ \\ ${ }^{1}$ Department of Chemistry, Water and Wastewater Technology, Faculty of Infrastructure and \\ Environment, Czestochowa University of Technology, ul. Dabrowskiego 69, \\ 42-200 Czestochowa, Poland
}

\begin{abstract}
The assessment of changes in air pollution quality for 4 selected sites in Southern and Central Poland was presented in this paper. The evaluation was based on the sets of long-term data, recorded by the state air monitoring network. Concentrations of $\mathrm{O}_{3}, \mathrm{PM}_{10}, \mathrm{SO}_{2}, \mathrm{NO}_{\mathrm{x}}$, and $\mathrm{CO}$, were considered. The basis for the calculations were 12-year time series of hourly concentrations. Using the hourly data, the monthly averages were calculated to illustrate seasonal changes of pollutant concentrations. Linear trends were adjusted to the concentration courses with the least squares method. Long-time trends were calculated for each pollutant separately. Based on the analysis of the trend lines slopes, risks those may arise in the future were identified.
\end{abstract}

\section{Introduction}

Before the accession to the European Union Poland had the reputation of a country with heavily polluted air. Joining the EU in 2004 was connected with the adoption of European standards of air protection, including a significant reorganization of the air monitoring system. At that time, a new air monitoring network was established that operates and collects data according to European standards up to the present [1, 2]. Long-term measurements of the air monitoring stations allow to answer the question how the air quality has changed in time.

One way of air quality evaluation is to identify trends in monitoring time series. The aim of the study was to identify the trends of changes in the concentration levels of main air pollutants at some different localisations in Poland. In this examination, 2005 was adopted as the starting point in the analysed time series. 12-year observations were used to determine the real trends. For various measuring stations and various air pollutants, a mathematical form of linear trends was found.

\section{Methods}

Concentrations of basic air pollutants such as: $\mathrm{O}_{3}, \mathrm{NO}_{\mathrm{x}}, \mathrm{CO}, \mathrm{SO}_{2}, \mathrm{PM}_{10}$, registered in the years 2005-2016 at four air monitoring stations in south and central Poland, were used in

\footnotetext{
*Corresponding author: szymon@is.pcz.czest.pl
} 
the analysis. Two stations Zabrze and Rybnik are located in big industrial cities and belong to the type of urban background monitoring sites [3]. The both stations are located in Upper Silesia, the most polluted area in Poland. The another two stations are located in central Poland, the first one in a quite big city Radom, and the second one in Granica, a village located in Kampinos National Park. The description of air monitoring sites was given in Table 1.

Table 1. The description of the air monitoring stations.

\begin{tabular}{|c|c|c|c|c|c|}
\hline No. & $\begin{array}{l}\text { Monitoring } \\
\text { site }\end{array}$ & Address/localisation & Data source & $\begin{array}{c}\text { Area } \\
\text { type }\end{array}$ & Station type \\
\hline 1. & Granica & $\begin{array}{l}125 / 2 \text { Granica, } \\
\text { Kampinos National Park, } \\
\text { Masovia, Central Poland }\end{array}$ & $\begin{array}{l}\text { Voivodeship Inspectorate } \\
\text { for Environmental } \\
\text { Protection in Warsaw }\end{array}$ & rural & $\begin{array}{c}\text { regional } \\
\text { background }\end{array}$ \\
\hline 2. & Radom & $\begin{array}{l}1 \text { Tochtermana Street, } \\
\text { Radom City } \\
\text { Masovia, Central Poland }\end{array}$ & $\begin{array}{l}\text { Voivodeship Inspectorate } \\
\text { for Environmental } \\
\text { Protection in Warsaw }\end{array}$ & urban & $\begin{array}{c}\text { urban } \\
\text { background }\end{array}$ \\
\hline 3. & Rybnik & $\begin{array}{c}\text { 37d Borki Street, } \\
\text { Rybnik City } \\
\text { Upper Silesia, South Poland }\end{array}$ & $\begin{array}{l}\text { Voivodeship Inspectorate } \\
\text { for Environmental } \\
\text { Protection in Katowice }\end{array}$ & urban & $\begin{array}{c}\text { urban } \\
\text { background }\end{array}$ \\
\hline 4. & Zabrze & $\begin{array}{c}34 \text { Curie-Skłodowska Street, } \\
\text { Zabrze City } \\
\text { Upper Silesia, South Poland }\end{array}$ & $\begin{array}{l}\text { Voivodeship Inspectorate } \\
\text { for Environmental } \\
\text { Protection in Katowice }\end{array}$ & urban & $\begin{array}{c}\text { urban } \\
\text { background }\end{array}$ \\
\hline
\end{tabular}

The analysed data were received from the Voivodeship Inspectorate of Environmental Protection in Katowice and from Inspectorate of Environmental Protection in Warsaw. Using time series of 1-hour (instantaneous) concentrations, the monthly mean concentrations were calculated. For each pollutant, 12-year courses of monthly concentrations were determined. Linear trends were adjusted to the courses with the least squares method. The obtained trends equations took the general form:

where:

$$
y=\mathrm{m} \cdot x+\mathrm{b}
$$

$y$ was the concentration,

$m$ was the slope of the line,

$x$ was the number of years after 2005

$b$ was the $y$ intercept (the value of concentration at the beginning of 2005).

The values of parameters $m$ and $b$, describing individual trend lines, were calculated. Using the slope values, the annual changes of concentrations were estimated for each trend line. Percentage annual changes in relation to the intercepts $(\mathrm{m} / \mathrm{b}) \cdot 100 \%$ were calculated to assess relative annual increments. The relative annual increments allow to compare changes in concentrations of various pollutants at different stations. Values of relative annual increments assumed as the basis for the classification of trends.

\section{Results}

Results of the analysis were presented in Figures 1-5. The figures show 12-year courses of monthly concentrations with adjusted trend lines, separately for each pollutant and for each 
site. At the monitoring station Granica concentrations of $\mathrm{PM}_{10}$ and $\mathrm{CO}$ were not measured, therefore there were no relevant courses.
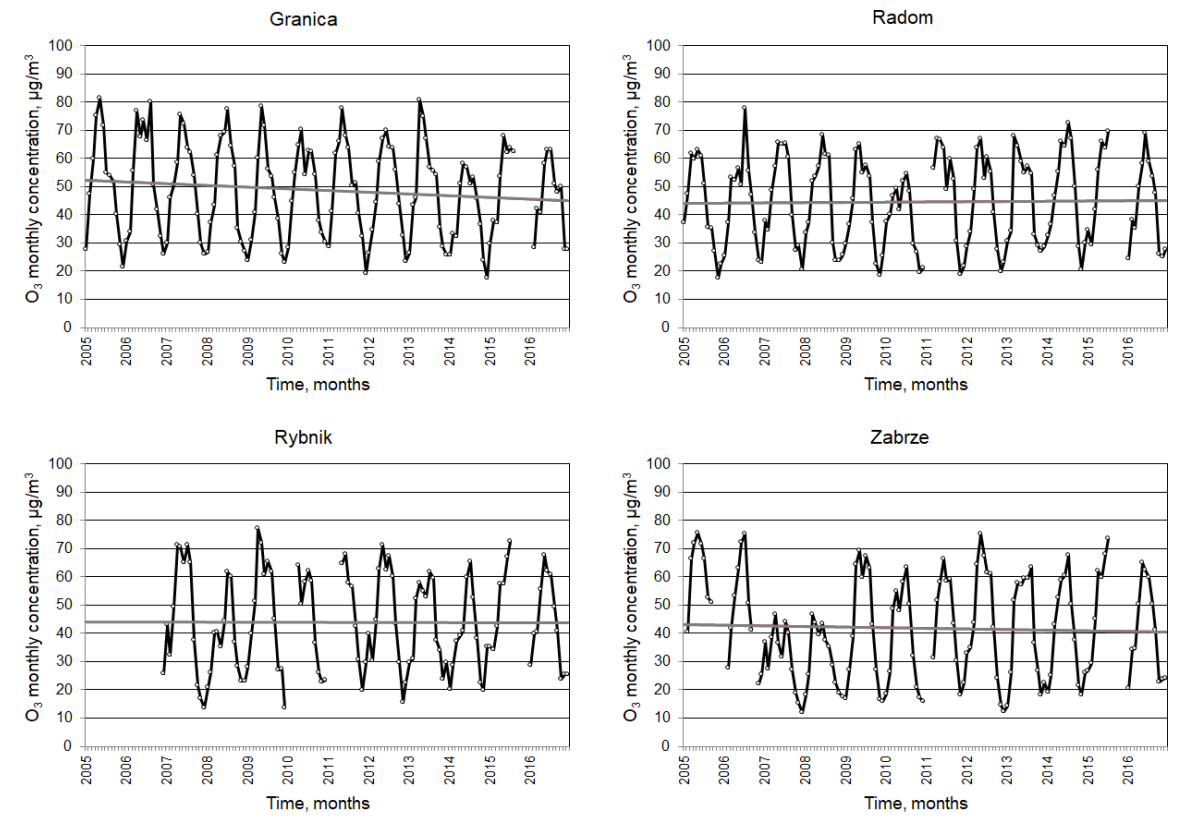

Fig. 1. The 12-year courses of monthly average concentrations of $\mathrm{O}_{3}$ at some different air monitoring stations, with adjusted linear trends.
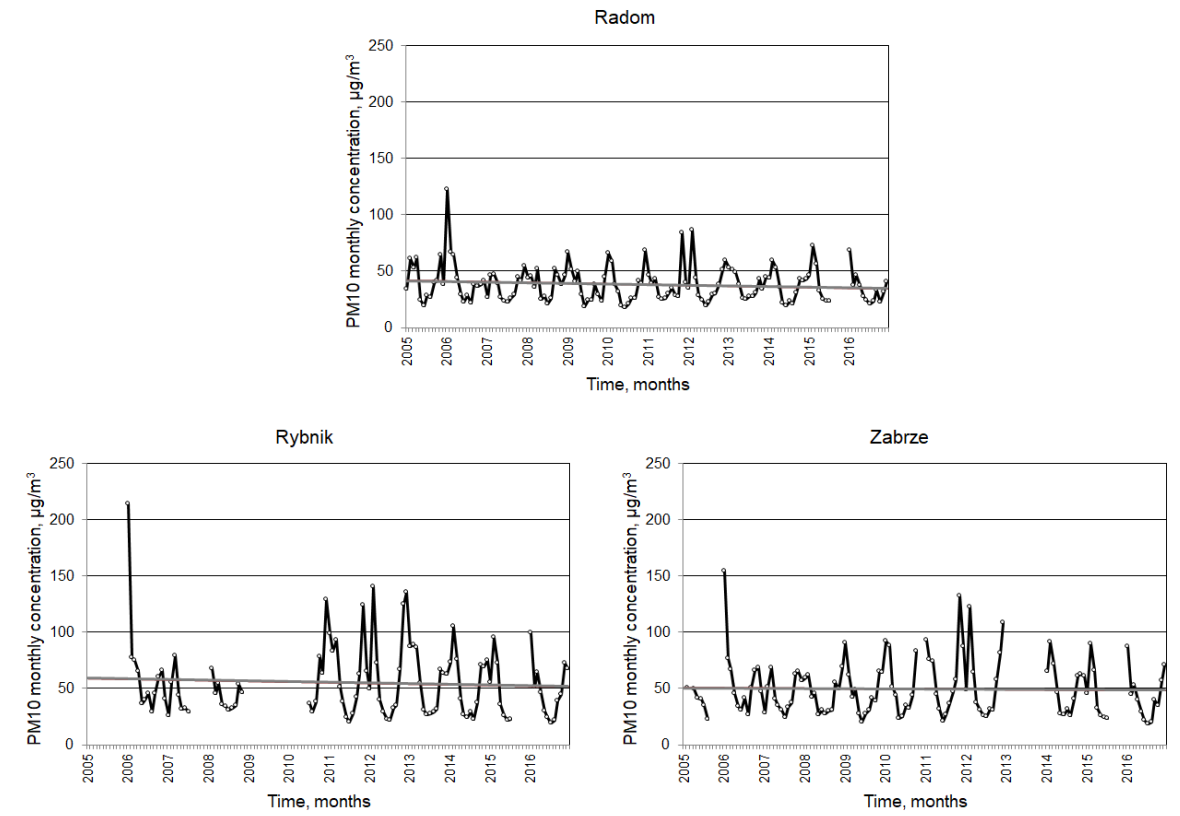

Fig. 2. The 12-year courses of monthly average concentrations of $\mathrm{PM}_{10}$ at some different air monitoring stations, with adjusted linear trends. 

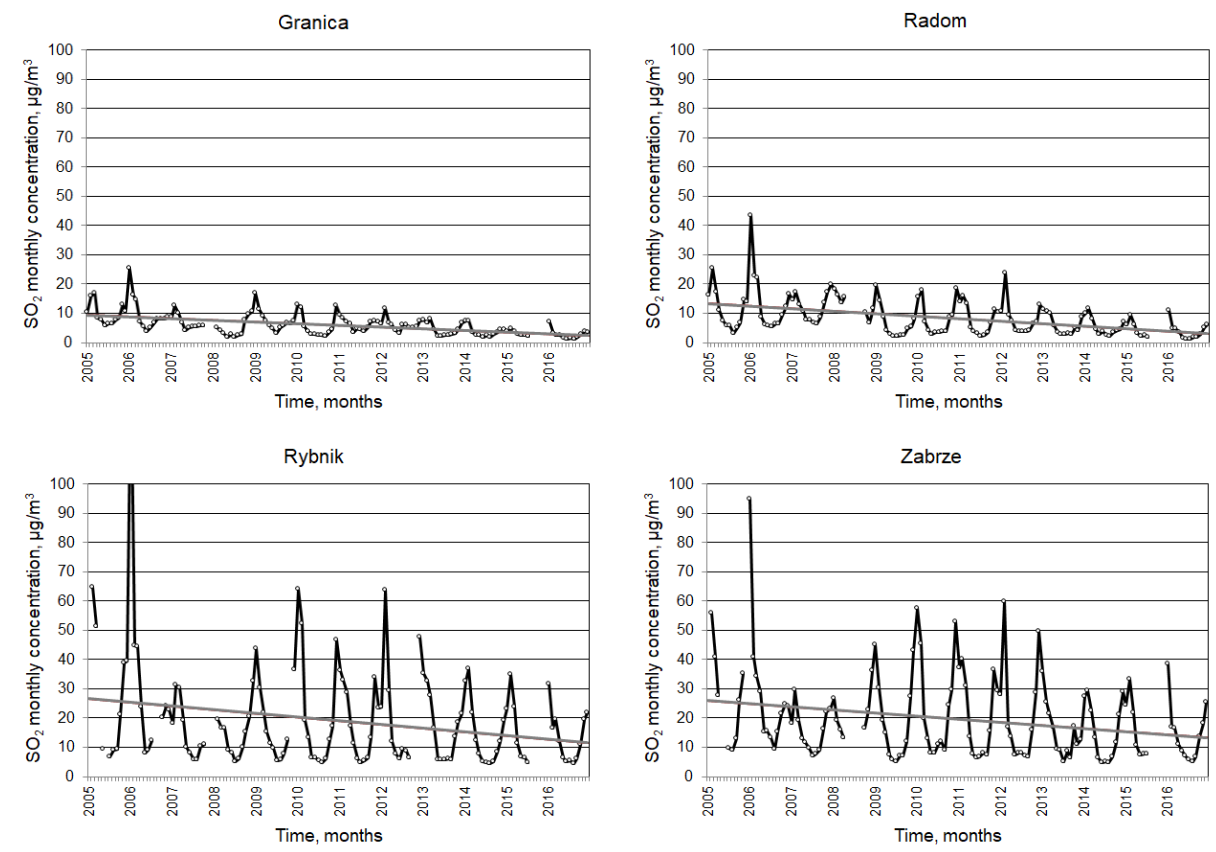

Fig. 3. The 12-year courses of monthly average concentrations of $\mathrm{SO}_{2}$ at some different air monitoring stations, with adjusted linear trends.
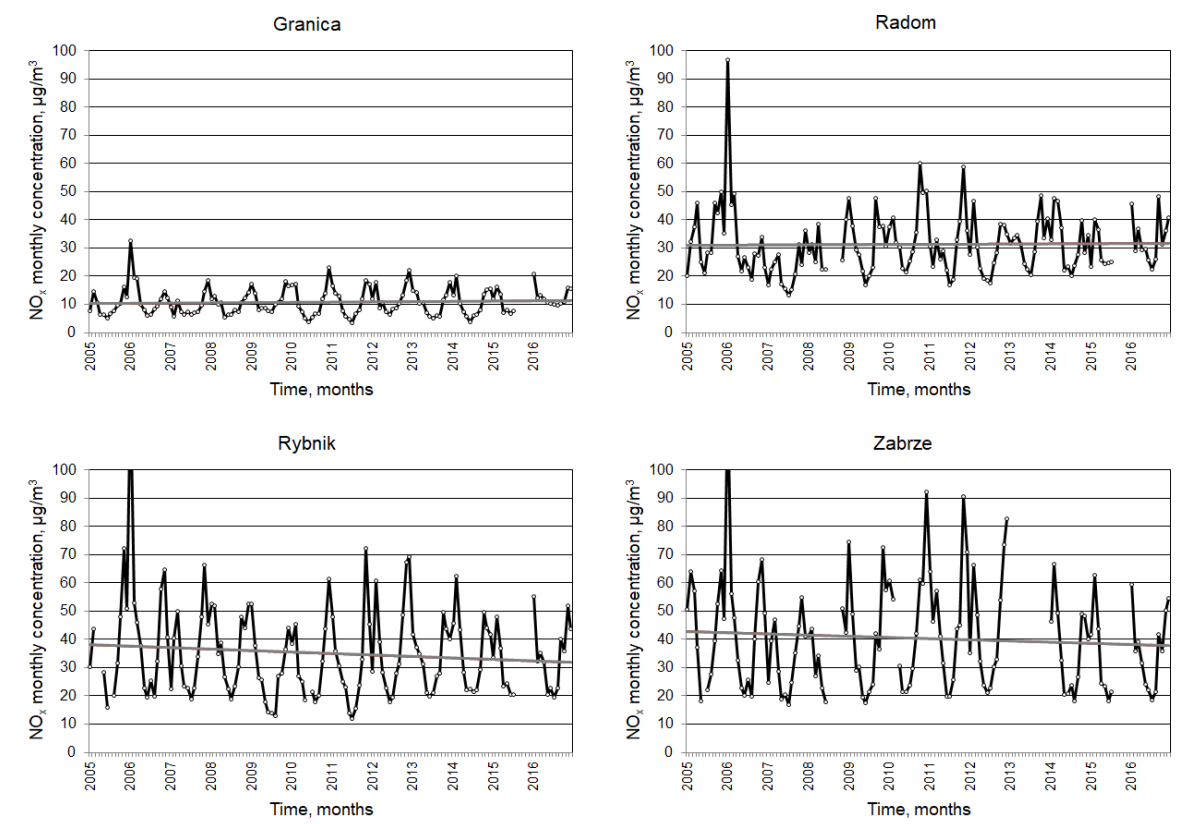

Fig. 4. The 12-year courses of monthly average concentrations of $\mathrm{NO}_{\mathrm{x}}$ at some different air monitoring stations, with adjusted linear trends. 

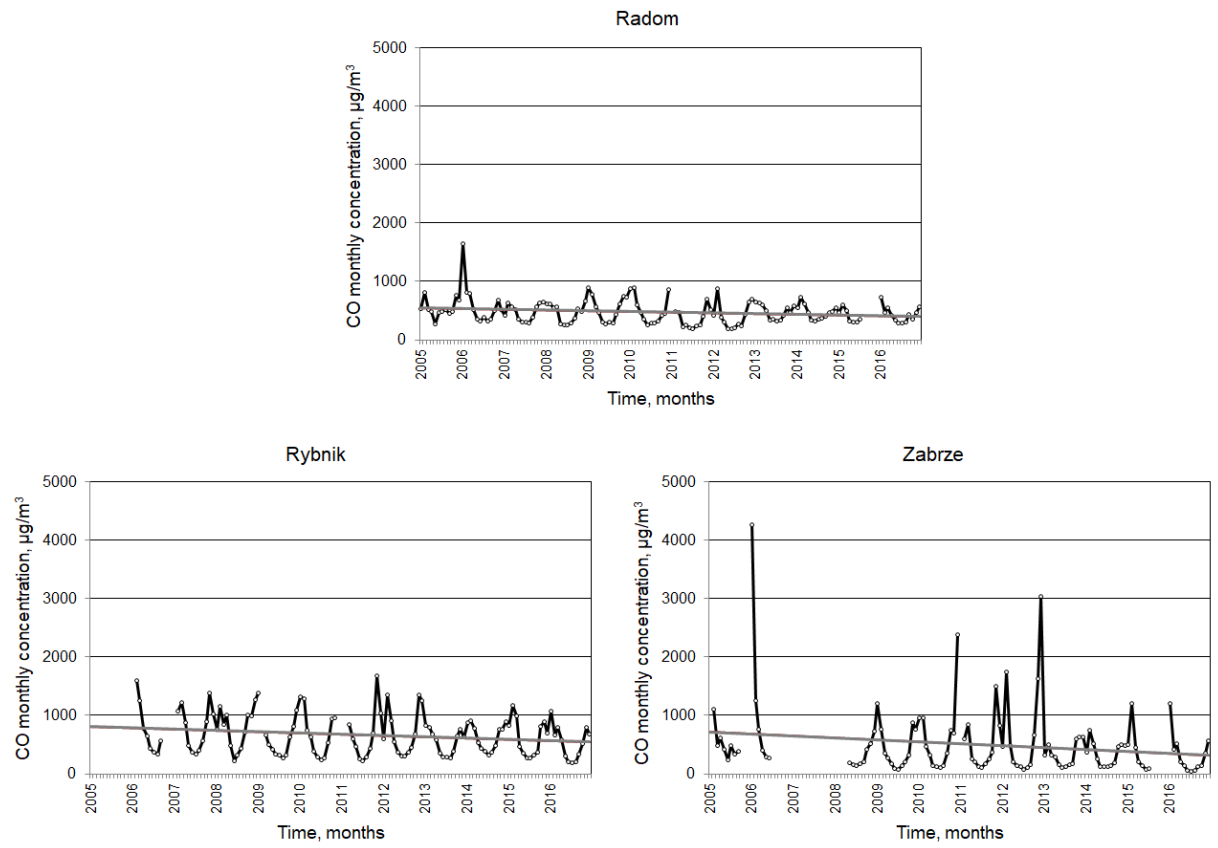

Fig. 5. The 12-year courses of monthly average concentrations of $\mathrm{CO}$ at some different air monitoring stations, with adjusted linear trends.

\section{Summary and discussion}

The direction coefficient values of the obtained trend equations were analysed to estimate the direction and the strength of concentrations changes. Summary of the results was included in Table 2. The table shows slope-intercept forms $(y=m \cdot x+b)$ of the individual trend equations, the values of parameters $\mathrm{m}$ and $\mathrm{b}$, relative annual increments (given in $\% /$ year), as well as estimation of trends.

In a very generalized assessment, concentrations of the most of main air pollutants tend to decrease. The strongest decreases are observed in the case of $\mathrm{SO}_{2}$ concentrations. The annual drops are in the range $4.07-6.46 \%$ per year. CO concentrations are also clearly reduced, at a rate of 2.20-4.68\%/year. Concentrations of $\mathrm{PM}_{10}$ decrease at all monitoring stations, but slower than $\mathrm{SO}_{2}$ and $\mathrm{CO}$ concentrations (0.35-1.35\% annually). Changes in $\mathrm{O}_{3}$ and $\mathrm{NO}_{\mathrm{x}}$ concentrations are not so significant, and they do not show consistent trends. They depend on the location of the air monitoring station. For example, at the rural station Granica, $\mathrm{NO}_{\mathrm{x}}$ concentrations tend to increase, while at Radom they are stable, but at Zabrze and Rybnik they drop.

According to Polish Central Statistical Office, since 2000 in Poland the following drops of emission has been estimated: $51 \%$ for $\mathrm{SO}_{2}, 25 \%$ for $\mathrm{CO}, 22 \%$ for $\mathrm{PM}, 14 \%$ for $\mathrm{NO}_{\mathrm{x}}$ [4]. The decreasing in concentrations of these pollutants in the ambient air is obviously related to the emission drops. Similar trends have been observed in other European countries. As it was reported by European Environment Agency, in the years 2000-2015 total emissions of the mentioned air pollutants also decreased in EU [5].

Generally, the changes in pollution levels at 4 examined sites should be considered advantageous for the environment. The rapid fall in $\mathrm{SO}_{2}$ and $\mathrm{CO}$ levels indicates an 
effective policy of reducing air pollution threat. Several years ago Poland was classified as a country with exceptionally high $\mathrm{SO}_{2}$ emission. The evident drop of $\mathrm{SO}_{2}$ concentrations indicates that long-term programs for limitation emission of this gas are resultful. Noteworthy is the fact that decreasing trends are noticeable in Upper Silesia, the most polluted Polish region where coal is mined and burned on a large scale.

Table 2. Long-term concentration changes - summary.

\begin{tabular}{|c|c|c|c|c|c|c|}
\hline Pollutant & $\begin{array}{c}\text { Monitoring } \\
\text { site }\end{array}$ & $\begin{array}{l}\text { Slope-intercept } \\
\text { form of trend } \\
\text { equation } \\
\text { (x- number of } \\
\text { year in the time } \\
\text { series) }\end{array}$ & $\begin{array}{l}\text { The slope of } \\
\text { a trend line } \\
\text { m, } \\
\left(\mu \mathrm{g} / \mathbf{m}^{3}\right) / \text { year }\end{array}$ & $\begin{array}{c}\text { The } \\
\text { intercept } \\
\text { b, } \\
\mu \mathrm{g} / \mathbf{m}^{3}\end{array}$ & $\begin{array}{c}\text { Relative } \\
\text { annual } \\
\text { increments } \\
(\mathbf{m} / \mathbf{b}) \cdot 100 \% \text {, } \\
\text { \%/year }\end{array}$ & $\begin{array}{c}\text { Estimation of } \\
\text { trend }\end{array}$ \\
\hline \multirow{4}{*}{$\mathrm{O}_{3}$} & Granica & $y=-0.612 x+52.4$ & -0.612 & 52.4 & -1.17 & Decrease \\
\hline & Radom & $y=0.083 x+44.1$ & 0.083 & 44.1 & 0.19 & Stabilization \\
\hline & Rybnik & $y=-0.009 x+44.0$ & -0.009 & 44.0 & -0.02 & Stabilization \\
\hline & Zabrze & $y=-0.222 x+43.2$ & -0.222 & 43.2 & -0.51 & Decrease \\
\hline \multirow{4}{*}{$\mathrm{PM}_{10}$} & Granica & - & - & - & - & - \\
\hline & Radom & $y=-0.562 x+41.5$ & -0.562 & 41.5 & -1.35 & Decrease \\
\hline & Rybnik & $y=-0.617 x+59.3$ & -0.617 & 59.3 & -1.04 & Decrease \\
\hline & Zabrze & $y=-0.178 x+50.7$ & -0.178 & 50.7 & -0.35 & Slight decrease \\
\hline \multirow{4}{*}{$\mathrm{SO}_{2}$} & Granica & $y=-0.602 x+9.5$ & -0.602 & 9.5 & -6.34 & Strong decrease \\
\hline & Radom & $y=-0.866 x+13.4$ & -0.866 & 13.4 & -6.46 & Strong decrease \\
\hline & Rybnik & $y=-1.264 x+26.8$ & -1.264 & 26.8 & -4.72 & Strong decrease \\
\hline & Zabrze & $y=-1.061 x+26.1$ & -1.061 & 26.1 & -4.07 & Strong decrease \\
\hline \multirow{4}{*}{$\mathrm{NO}_{\mathrm{x}}$} & Granica & $y=0.091 x+10.3$ & 0.091 & 10.3 & 0.88 & Increase \\
\hline & Radom & $y=0.058 x+31.1$ & 0.058 & 31.1 & 0.19 & Stabilization \\
\hline & Rybnik & $y=-0.523 x+38.2$ & -0.523 & 38.2 & -1.37 & Decrease \\
\hline & Zabrze & $y=-0.433 x+42.9$ & -0.433 & 42.9 & -1.01 & Decrease \\
\hline \multirow{4}{*}{$\mathrm{CO}$} & Granica & - & - & - & - & - \\
\hline & Radom & $y=-11.95 x+544$ & -11.95 & 544 & -2.20 & Decrease \\
\hline & Rybnik & $y=-21.75 x+806$ & -21.75 & 806 & -2.70 & Decrease \\
\hline & Zabrze & $y=-33.67 x+719$ & -33.67 & 719 & $-4,68$ & Strong decrease \\
\hline
\end{tabular}

Trends observed in Poland coincide with European trends. Europe's air quality is slowly improving, but particulate matter (PM) and ground-level ozone continue to cause serious impacts on health [6]. According to European Environment Agency the biggest problem in Poland are PM concentrations [7]. It is estimated that every year in Poland over 44,000 people die prematurely due to high concentrations of fine particular matter [8]. The problem concerns especially the southern voivodeships. Although the gradual decrease in concentration can be noted, but still the levels of concentration during heating periods are too high. Monthly concentrations of $\mathrm{PM}_{10}$ may still exceed $100 \mu \mathrm{g} / \mathrm{m}^{3}$, as the graphs in Figure 2 show. The main reason is emission from very common domestic installations that burn coal waste. It can be assumed that smog episodes resulting from high concentrations of $\mathrm{PM}_{10}$ will continue to occur in Poland, because government politicians want to maintain the leading role of coal in the Polish power industry and economy.

\section{Conclusions}

The long-term observations of concentration levels of the basic pollutants registered at four air monitoring stations allow the following conclusions:

1. Concentrations of the most of main air pollutants tend to decrease. 
2. The strongest drops are observed in the case of $\mathrm{SO}_{2}$ concentrations. The annual drops are in the range $4.1-6.5 \%$.

3. CO concentrations are also evidently reduced (2.2-4.7\% annually).

4. Concentrations of $\mathrm{PM}_{10}$ decrease slower (0.35-1.35\% annually).

5. Changes in $\mathrm{O}_{3}$ and $\mathrm{NO}_{\mathrm{x}}$ concentrations are not significant, and they do not show consistent trends. They depend on the location of the air monitoring station.

This study was carried out within a research project of Czestochowa University of Technology BS-PB-402-301/15.

\section{References}

1. Ustawa z dnia 27 lipca 2001 r. Prawo ochrony środowiska, Dz.U. 2001 nr 62, poz. 627 (2001)

2. Główny Inspektor Ochrony Środowiska, Program państwowego monitoringu środowiska na lata 2003-2005 (Warszawa, 2003)

3. Inspekcja Ochrony Środowiska, Wojewódzki Inspektorat Ochrony Środowiska w Katowicach, Stan środowiska w województwie śląskim w 2016 roku (Biblioteka Monitoringu Środowiska, Katowice, 2017)

4. Central Statistical Office GUS, Environment 2017 (Warsaw, 2017), available on website www.stat.gov.pl

5. European Environment Agency, Air quality in Europe - 2017 report (No 13/2017, Publications Office of the European Union, Luxembourg, 2017)

6. Główny Inspektorat Ochrony Środowiska, Stan środowiska w Polsce - Raport 2014 (Biblioteka Monitoringu Środowiska, Warszawa, 2014)

7. European Environment Agency, The European environment - state and outlook 2015: synthesis report (Copenhagen, 2015)

8. European Environment Agency, Air quality in Europe - 2018 report (No. 12/2018, Publications Office of the European Union, Luxembourg, 2018) 